\title{
KHỐI BẤT THƯờnG NHĨ PHẢI: HUYẾT KHỐI HAY U TIM ?
}

\section{Phạm Quốc Đạt*, Dưong Đức Hùng*, Lê Việt Thắng*, Vũ Công Hiếu*}

\section{I. ĐẠTT VẤN ĐỀ}

Chẩn đoán phân biệt của khối bất thường trong tim bao gồm: huyết khối, u tim. Kích thước, hình dạng, vị trí, tính di động, mật độ kết hợp với các triệu chứng lâm sàng để chẩn đoán phân biệt các nguyên nhân. Siêu âm tim qua thành ngực và đặc biệt là siêu âm qua thực quản trở thành tiêu chuẩn để chẩn đoán các khối bất thường trong tim. Chụp cắt lớp vi tính, cộng hưởng từ tim cũng là một phương tiện để chẩn đoán với độ chính xác cao [1]. Chẩn đoán chính xác nguyên nhân là rất quan trọng trong lựa chọn giải pháp điều trị thích hợp và tiên lượng bệnh nhân.

Chúng tôi báo cáo một trường hợp có khối bất thường nhĩ phải nhằm thảo luận các chẩn đoán có thể xảy ra trên bệnh nhân và nhìn lại y văn các nguyên nhân gây ra khối bất thường trong nhĩ phải.

\section{CA LÂM SÀNG}

Bệnh nhân nữ 44 tuổi. Tiền sử có bố và chị gái mất vì ung thư phổi. Bệnh diễn biến 1 tháng, với triệu chứng khó thở khi gắng sức, ngày càng tăng. 4 ngày trước vào viện bệnh nhân xuất hiện phù 2 chi dưới kèm theo chướng bụng.

Khám: NYHA II, phù 2 chi dưới, bụng cổ chướng, gan to $5 \mathrm{~cm}$ dưới bờ sườn, mật độ mềm, tĩnh mạch cổ nổi. Thổi tâm thu nhẹ ổ van ba lá.

Siêu âm tim: Trong lòng nhĩ phải có khối đậm âm tương đối đồng nhất, kích thước $70 \mathrm{x}$ $45 \mathrm{~mm}$; không liên quan đến tổ chức van ba lá, không xâm lấn tĩnh mạch chủ. Khối có cuống bám vào vách liên nhĩ, di động mạnh qua lỗ van ba lá thời kỳ tâm trương, chiếm gần hết lỗ van ba lá. Chênh áp qua van ba lá thì tâm trương $15 / 13 \mathrm{mmHg}$. Ít dịch màng ngoài tim, tỷ trọng thấp. Chức năng tim và các van tim khác bình thường (hình 1).
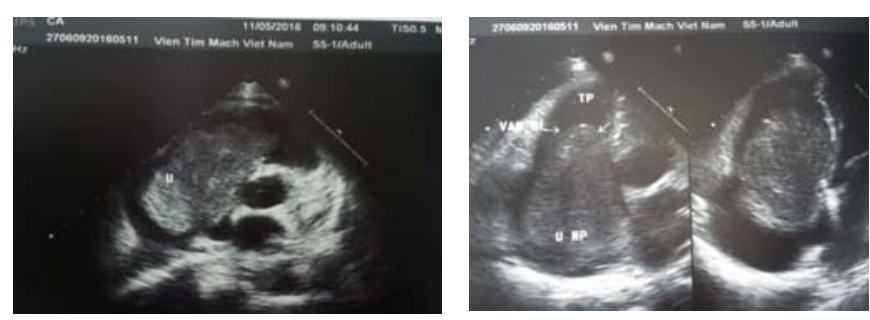

Hình 2.1.Khối bất thường nhĩ phải trên siêu

\section{âm tim}

Cộng hưởng từ: Nhĩ phải có khối kích thước: $62 \times 33 \mathrm{~mm}$; cuống bám vào vách liên nhĩ, không liên quan đến tĩnh mạch chủ trên và tĩnh mạch chủ dưới, di động 1 phần vào thất phải trong thì tâm trương. Khối tăng mạch tín hiệu trên thì STIR, giảm trên ảnh cine và ngấm thuốc ít sau tiêm. Chức năng tim bình thường, các buồng tim không giãn (hình 2).
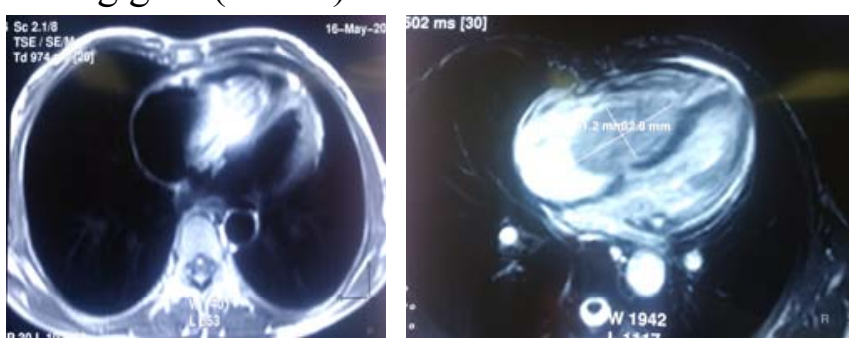

\section{Hinh 2.2. Khối bất thường nhĩ phải trên cộng hưởng tù}

Điện tâm đồ: nhịp xoang 80 chu kỳ/phút, không có dấu hiệu thiếu máu cơ tim.

Siêu âm mạch chi dưới, mạch chủ: không có huyết khối hệ tĩnh mạch.

Bệnh nhân được làm các xét nghiệm nhằm loại trù u di căn.

Siêu âm/CT bụng: Gan to, dịch ổ bụng. Không phát hiện u ở các tạng trong ổ bụng.

CT/X-Quang phổi, soi dạ dày, đại tràng,

\footnotetext{
* Đon vị phẫu thuật Tim mạch C8, Viện Tim mạch, Bệnh viện Bạch Mai Ngưòi chịu trách nhiệm khoa học: TS. Duoong Đúc Hùng Ngày nhận bài: 01/08/2017 - Ngày Cho Phép Đăng: 07/08/2017 Phản Biện Khoa hoc: PGS.TS. Đặng Ngocc Hùng GS.TS. Lê Ngọc Thành
} 
Siêu âm/X-Quang tuyến vú: Không phát hiện bất thường.

Xạ hình xương: bình thường

Marker ung thu: AFP: 2,21 ng/ml; CA 19-9: 13,29; CA 15-3: 15,43 U/ml; CA 12-5: 155,7 $\mathrm{U} / \mathrm{ml}$; CA 72-4: 1,71 U/ml

Chẩn đoán trước mổ: $U$ nhày nhĩ phải (myxomas)

Phẫu thuật: Thiết lập hệ thống tuần hoàn ngoài cơ thể. Tổn thương trong mổ: khối lớn kích

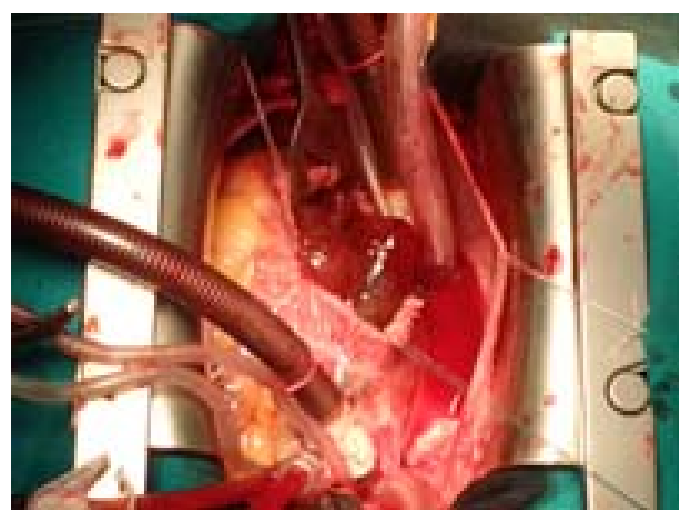

thước $6 \times 4 \times 3 \mathrm{~cm}$ chiếm gần toàn bộ nhĩ phải và sa một phần qua van ba lá xuống thất phải, khối màu nâu nhạt, hơi trong, bề mặt mịn, chia múi, đặc, có cuống bám vào lỗ bầu dục với chân đường kính $5 \mathrm{~mm}$, không thấy xâm lấn tổ chức xung quanh. Tiến hành: lấy $\mathrm{u}$, cắt toàn bộ chân $\mathrm{u}$ cùng lỗ bầu dục, vá lại lỗ bầu dục bằng màng tim (hình 3 ). Thời gian chạy máy: 45 phút; thời gian cặp động mạch chủ 20 phút.

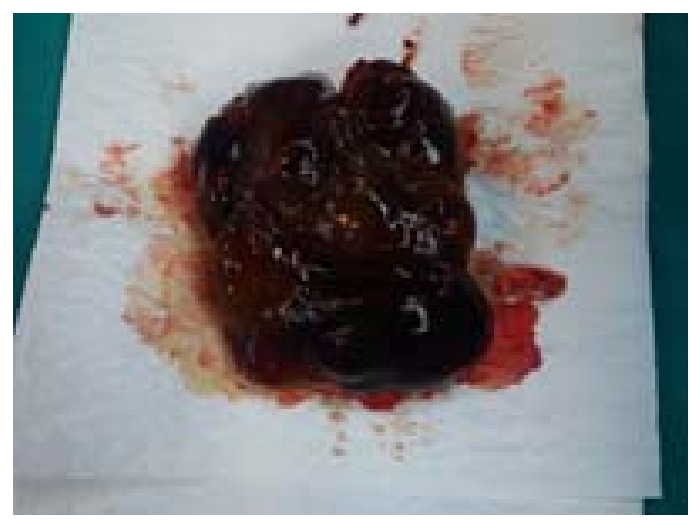

\section{Hình 2.3. Khối bất thường nhĩ phải trong mổ}

\section{Hậu phẫu:}

Bệnh nhân được rút nội khí quản ngày thứ nhất.

Siêu âm kiểm tra sau mổ: kết quả tốt

Bệnh nhân ra viện sau 1 tuần. Lâm sàng: gan không to, hết phù, hết khó thở. nhày

Giải phẫu bệnh khẳng định lại chẩn đoán: $U$

\section{BÀN LUẬN}

\subsection{U tim nguyên phát, $u$ tim di căn}

U tim chiếm khoảng $0,2 \%$ tất cả các loại u trong cơ thể con người, bao gồm $\mathrm{u}$ tim nguyên phát và thứ phát hay u di căn [2].

\subsubsection{U tim nguyên phát}

U tim nguyên phát khá hiếm và khoảng $75 \%$ là lành tính, trong số đó $50 \%$ là u nhày, u nhày chiếm tỷ lệ $0,0017 \%$ trong dân số. Các loại u lành tính khác có thể gặp là:lipomas, fibromas, rhabdomyomas. Khối u ác tính nguyên phát thường gặp nhất là sarcoma [2].

\section{U nhày}

Về mặt mô bệnh học, u nhày là một u thực sự, xuất phát từ tế bào trung mô của lớp nội tâm mạc [2]. U nhày nhĩ phải là vị trí không thường xuyên gặp, chiếm $15-20 \%$ các ca u nhày [3].U nhày biểu hiện ở bất kỳ độ tuổi nào ( 15 đến 80 tuổi) và trung bình khoảng 50 tuổi, nữ nhiều hơn nam. Khoảng $7 \%$ có liên quan đến di truyền nhiễm sắc thể thường. Với dạng này thường có đặc điểm xảy ra ở nam giới trẻ tuổi và có nguy cơ tái phát sau phẫu thuật [4].

U nhày nhĩ phải thường xuất phát từ lỗ bầu dục hoặc vách liên nhĩ [5]. U nhày thường đơn độc, chia nhiều thùy và có cuống $(83 \%$ các trường hợp). Trong một báo cáo kinh nghiệm 19 năm phẫu thuật $u$ nhày, có 7/41 trường hợp (17\%) xuất phát từ nhĩ phải. [6]. Về mặt đại thể, bề mặt $\mathrm{u}$ nhày thường mịn và chia múi, hình bầu dục hoặc tròn. $U$ thường có màu nâu nhạt. Mật độ $u$ cũng thay đổi từ cứng đến dạng sền sệt. Đặc điểm vi thể là một mạng lưới dày đặc các tế bào chế nhày, trong đó có thể tìm thấy tế bào đa giác với tế bào ưa kiềm. Không có các đặc điểm ác tính như phân chia, hoại tử hay tính đa hình [6].

Những biểu hiện và triệu chứng của $\mathrm{u}$ nhày 
nhĩ phải không điển hình và rất thay đổi, phụ thuộc vào kích thước, vị trí, độ di động của u và tư thế của bệnh nhân. U nhày nhĩ phải có thể không có triệu chứng [7], hoặc có thể gây ra các triệu chứng không đặc hiệu như: sốt, sụt cân, đau khớp, hiện tượng Raynaud, thiếu máu, tăng gammaglobulinemia hay protein $\mathrm{C}$, tăng tốc độ máu lắng do ảnh hưởng của interleukin-6 [8]. Một số nghiên cứu gần đây đưa ra gợi ý rằng $\mathrm{u}$ nhày sản sinh và giải phóng vào tuần hoàn các yếu tố viêm interleukin, gây ra các phản ứng viêm hay hiện tượng tự miễn. Những triệu chứng này thường hoàn toàn mất đi khi cắt khối u [6].

Bệnh nhân cũng có thể biểu hiện triệu chứng đau ngực không điển hình, cảm giác khó chịu, ngất, hôn mê, hồi hộp, trống ngực, phù ngoại vi, tắc mạch phổi, ho máu. Tuy nhiên biểu hiện thường gặp nhất là khó thở $(80 \%)$ và triệu chứng của suy tim phải. U nhày nhĩ phải gây tắc nghẽn van ba lá, gây ra triệu chứng suy tim phải, phù, gan to, cố chướng, stĩnh mạch cổ nổi, ngất [4],[6],[9]. Triệu chứng nghe tim có thể thấy tiếng thổi hoặc không tùy thuộc vào vị trí, kích thước, độ di động, u có di động qua van nhĩ thất hay không, hay thậm chí phụ thuộc vào tư thế của người bệnh.

Mặc dù siêu âm tim qua thành ngực là một phương pháp ít xâm lấn nhưng có độ đặc hiệu lên đến $95 \%$ cho u nhày và độ đặc hiệu có thể lên đến $100 \%$ với siêu âm qua thực quản. Chụp cắt lớp và cộng hưởng từ có thể có ích trong việc đánh giá vị trí của cuống $\mathrm{u}$, liên quan của $\mathrm{u}$ với tổ chức xung quanh và các biến chứng liên quan. Chụp $\mathrm{X}$ quang phổi và điện tâm đồ là không đặc hiệu [9].

Khi chẩn đoán là $u$ nhày thì phẫu thuật cắt $\mathrm{u}$ cần được thực hiện càng sớm càng tốt để ngăn ngừa nguy cơ tắc mạch [8]. Thông thường, phẫu thuật là triệt căn và rất hiếm khi tái phát.Tỷ lệ tái phát của u rất thấp: $1-3 \%$. Tỷ lệ tử vong chiếm 0 $3 \%$ tùy từng nghiên cứu [9]. Kỹ thuật cắt bỏ u thường không khó, chú ý clamp cả động mạch chủ và động mạch phổi trong quá trình cắt $u$ để tránh tắc mạch phổi do các mạch u có thể vỡ ra trôi lên phồi [5].

\section{khác: \\ 3.1.2. Các khối u nguyên phát lành tính \\ U mõ (lipomas) có đặc điểm là khối đậm âm,}

đồng nhất và tăng tín hiện trên $\mathrm{T} 1 \mathrm{~W}$, không ngấm thuốc khi tiêm [2].Rhabdomyomas thường nhỏ và nhiều khối nằm trong thành của tâm thất (thất trái $80 \%$; thất phải $15 \%$ ). Fibromas nằm trong thành vách liên thất hoặc thành tự do của thất trái. Hai loại $\mathrm{u}$ này thường không gây ra triệu chứng tắc mạch mà thường ảnh hưởng đến van hai lá hoặc van động mạch chủ gây ra thay đổi về huyết động hoặc gây rối loạn nhịp. Rhabdomyomas và fibromas thường chỉ gặp ở trẻ sơ sinh và trẻ nhỏ [2].

3.1.3. U nguyên phát ác tính: chiếm khoảng $25 \%$ các loại u tim nguyên phát. $U$ ác tính thường gặp nhất là sarcoma. U có thể gặp ở bất kỳ tuồi nào nhưng thường ở độ tuổi 20-40 tuổi. Tỷ lệ nam/nữ là bằng nhau. Đặc điểm của u là phát triển nhanh, xâm lấn tổ chức xung quanh gây giảm chức năng tim. Trên phim chụp, $u$ thường ngấm thuốc mạnh sau tiêm [2].

\subsection{U di căn}

U di căn thường nhiều hơn gấp 20-40 lần u nguyên phát ác tính [2]. Ung thư bạch cầu và u hắc tố là hai loại u có tỷ lệ di căn tim cao nhất, lần lượt là 53,9 và $34 \%$. Ung thư phổi, sarcoma, ung thư vú, ung thư thực quản, ung thư buồng trứng, ung thư tế bào thận lần lượt chiếm tỷ lệ $10,2 \%, 9,2 \%, 8,3 \%, 7,7 \%, 5,7 \%$ và $5,3 \%$. Các khối u đường tiêu hóa và tiền luyệt tuyến hiếm khi di căn tim. U lympho thường liên quan đến màng ngoài tim hơn là $u$ trong tim. Hầu hết $u$ di căn đến tim theo đường máu, ngoài ra còn theo các đường bạch huyết, tĩnh mạch chủ dưới, tĩnh mạch phổi hoặc xâm lấn trực tiếp trong ung thư phổi, thực quản, tuyến ức và ung thư vú. Ung thư thận, gan, tuyến thượng thận, niệu quản di căn đến nhĩ phải qua đường tĩnh mạch chủ dưới. Khoảng $10 \%$ ung thư thận là có liên quan đến tĩnh mạch chủ dưới và $40 \%$ trong số đó là có liên quan đến nhĩ phải [10]. Bệnh nhân của chúng tôi được làm toàn bộ các xét nghiệm nhằm loại trừ nguyên nhân khối trong tim là do ung thư nơi khác di căn đến.

\subsection{Huyết khối}

Nguyên nhân gây huyết khối trong tim bao gồm: tổn thương lớp nội mạc, dòng máu bị ứ hoặc chảy chậm trong tim, hoặc dotình trạng tăng đông.

Tổn thương nội mạc có thể là kết quả của nhồi máu cơ tim, viêm cơ tim, phản ứng miễn 
dịch với cơ tim, hóa chất, tia xạ, các dụng cụ trong tim (catheter, máy tạo nhịp, chống rung...) hay là kết quả của phản ứng thải ghép [11].

Yếu tố gây ra dòng máu lưu thông chậm gây ra huyết khối trong tim thường do nhĩ giãn,rung nhĩ hoặc tim co bóp yếu [11].

Tăng đông là nguyên nhân không thường xuyên gây ra huyết khối buồng tim, có thể tăng đông nguyên phát do bất thường về gen hoặc thứ phát. Tăng đông nguyên phát hay tăng đông bao gồm bất thường của antithrombin III, protein $\mathrm{C}$, protein $\mathrm{S}$ và fibrinogen, yếu tố $\mathrm{V}$. Tăng đông thứ phát bao gồm: ung thư, bạch cầu cấp, hội chứng thận hư, thuốc tránh thai, có thai, hội chứng đông máu nội mạch rải rác (DIC), hội chứng kháng phospholipid, lupus ban đỏ, thiếu máu hồng cầu hình liềm, tăng tiểu cầu...[11].

Ngoài ra huyết khối trong tim còn bắt nguồn từ huyết khối tĩnh mạch sâu ở chân di chuyển vào buồng tim[11].

Bệnh nhân của chúng tôi cũng được loại trừ nguyên nhân huyết khối vì bệnh nhân không có các yếu tố thuận lợi gây huyết khối như: chức năng tim thấp, rối loạn nhịp, dị vật trong buồng tim hay huyết khối tĩnh mạch sâu và hình ảnh khối bất thường nhĩ phải không có đặc điểm huyết khối trên siêu âm cũng như cộng hưởng từ.

\section{KẾT LUẪN}

Tóm lại,với một khối bất thường trong tim cần chẩn đoán phân biệt giữa huyết khối, u tim nguyên phát hay u di căn. Ngoài các biểu hiện lâm sàng, cần phải kết hợp với các phương tiện cận lâm sàng như siêu âm tim qua thành ngực, qua thực quản hay hay cắt lớp vi tính và cộng hưởng từ để có chẩn đoán chính xác. Dựa vào đó để có hướng điều trị phù hợp và tiên lượng đúng cho bệnh nhân.

\section{TÀI LIÊUU THAM KHẢO}

1. Araoz PA, Mulvagh SL, Tazelaar HD, Julsrud PR, Breen JF. CT and MR imaging of benign primary cardiac neoplasms with echocardiographic correlation. Radiographics 2000;20:1303-19.
2. Reynen K, Frequency of primary tumors of the heart. Am J Cardiol 1996, 77:107.

3. Diaz A, Di Salvo C, Lawrence D, Hayward M. Left atrial and right ventricular myxoma: an uncommon presentation of a rare tumour. Interact Cardiovasc Thorac Surg 2011, 12:622-623.

4. Oliveira R, Branco L, Galrinho A, Abreu A, Abreu J, Fiarresga A, Mamede A, Ramos R, Leal A, Pinto E, Fragata J, Ferreira R. Cardiac myxoma: a 13-year experience in echocardiographic diagnosis . Rev Port Cardiol 2010, 29:1087-1100.

5. Stolf NA, Benício A, Moreira LF, Rossi E: Right atrium myxoma originating from the inferior vena cava: an unusual location with therapeutic and diagnostic implications. Rev Bras Cir Cardiovasc 2000, 15:255-258.

6. Samanidis G, Perreas K, Kalogris $P$, Dimitriou S, Balanika M, Amanatidis G, Khoury M, Michalis A: Surgical treatment of primary intracardiac myxoma: 19 years of experience. Interact Cardiovasc Thorac Surg 2011, 13:597-600.

7. Yuce M, Dagdelen S, Ergelen M, Eren N, Caglar N: A huge obstructive myxoma located in the right heart without causing any symptom. Int J Cardiol 2007, 114:405-406

8. Guhathakurta S, Riordan JP: Surgical treatment of right atrial myxoma. Tex Heart Inst J 2000, 27:61-63.

9. Croti UA, Braile DM, Souza AS, Cury PM. Right ventricle and tricuspid valve myxoma. Rev Bras Cir Cardiovasc 2008, 23:142-144.

10. Perry MC. Cardiac metastasis. In: Kapoor AS (ed). Cancer and the Heart. New York: Springer-Verlag Publishers, 1986.

11.Konkle BA, Schaffer AI. Hemostasis, thrombosis, fibrinolysis and cardiovascular disease. In: Zipes DP, Libby $\mathrm{P}$, Bonow RO, Braunwald E (eds). Braunwald's Heart Disease. Philadelphia: Elsevier Saunders, 2005; pp. 2075. 